\title{
Proceeding
}

8th INSHS International Christmas Sport Scientific Conference, 5-7 December 2013. International Network of Sport and Health

Science. Szombathely, Hungary

\section{The acceptable level of risk-taking for traditional rock climbers}

\author{
DAVID CHALOUPSKY \\ Department of Leisure and Tourism, Faculty of Informatics and Management, University of Hradec Kralove, Czech \\ Republic
}

\begin{abstract}
Chaloupsky, D. (2014). The acceptable level of risk-taking for traditional rock climbers. J. Hum. Sport Exerc., 9(Proc1), pp.S263-S269. Taking risk with all the consequences inevitably belongs to climbing. Each climber confronts his or her skills with the route he or she has chosen for an ascent. If the route is well protected, the rate of risk the climber takes is lower. If the route is less protected, the level of risk that the climber is exposed to proportionally increases. The aim of the research is to determine the level of risktaking in traditional climbing on sandstone. We focus on how the level of risk affects climber's performance and what reserve a climber needs to be able to cope with the higher risk and reduce it? The problem is solved by methods of quantitative research and the sample comprises more than 300 respondents. The results of the research prove a significant difference of climbers' performance in dependence on rate of risk. Climbers usually reach lower performance according to the grading scale when climbing traditional routes with a higher level of risk. Key words: ROCK CLIMBING, TRADITIONAL CLIMBING, SANDSTONE CLIMBING, PERFORMANCE, RATE OF RISK.
\end{abstract}

\footnotetext{
Corresponding author. University of Hradec Kralove, Faculty of Informatics and Management, Department of Leisure and Tourism Czech Republic. Rokitanskeho 62, 50003.

E-mail: david.chaloupsky@uhk.cz

8th INSHS International Christmas Sport Scientific Conference, 5-7 December 2013. International Network of Sport and Health Science. Szombathely, Hungary.

JOURNAL OF HUMAN SPORT \& EXERCISE ISSN 1988-5202

(C) Faculty of Education. University of Alicante

doi:10.14198/jhse.2014.9.Proc1.08
} 


\section{INTRODUCTION}

Climbing is a sport field where everyone can realize their potential. One climbs to the summits in the easiest possible way and enjoys beauty of nature and the surrounding countryside, while the other tries to climb the most difficult route. Climbing offers a wide range of disciplines that are extremely different from one another. For example there is bouldering on one hand and high altitude climbing on highest peaks on the other hand. Each discipline requires control of a certain level of risk. Taking risk with all the consequences inevitably belongs to climbing. Each climber confronts his or her skills with the route he or she has chosen for an ascent.

Researchers have focused on the psychological characteristic of risk takers. (e.g., Brody, Hatfield \& Spalding, 1988; Ewert, 1994; Pain \& Pain, 2005). Many papers cite Zuckerman (1994) and his "sensation seeking" behaviour. Other objectives of researchers are risk taking during rock climbing and epidemiology of injuries (e.g., Wright et al., 2001; Turner et al., 2004; Jones et al., 2007). Llewellyn et al. (2008) investigated relation between self-efficacy and a wide range of rock climbing behaviours in active rock climbers, climbing both indoor and outdoor.

Sports routes are characterized by very good fixed protection equipped with bolts. A potential fall of a climber is short and relatively safe into a solid fixed gear. Llewellyn \& Sanchez (2008) ranks sport climbing into a category of "high risk", while traditional climbing into a category of "medium risk". Climbing on traditional sandstone routes follows the rules of sandstone climbing (Český horolezecký svaz, 2005). If there are fixed rings for belaying, their mutual distance is much longer than in sports routes. Additional protection can be based only by the climbers themselves and only slings are allowed to be used. A fall during traditional sandstone rock climbing is often very long and dangerous, since the resistance of selfplaced protection and belay devices does not need to be sufficient enough. Therefore the level of risk in traditional sandstone climbing is much higher than in sport climbing. Sport climbing seems to be the least risky discipline according to safely fixed protection. The rate of risk in sandstone climbing is significantly higher. This statement is in accord with the works of several authors (Dieška, 1989; Neuman, 1989; Neuman et al., 2000; Llewellyn et al. 2008).

Many Czech climbers engage in both disciplines. They reach their own extreme performance given by the highest degree of difficulty they are able to climb. The difficulty of each route is given in climbing guides in the existing classification scales (Procházka, 1990). Neuman et al. (2000) confirmed that the most commonly used scales of difficulty in Europe are the UIAA scale and the French scale of difficulty for sports climbing and the Saxon scale for sandstone climbing. The number of sources gives conversion tables for different scales. Majority of routes worldwide are described and graded in climbing guides. The classification of each new route is proposed and submitted for a committee's approval. They either approve the proposed classification or adjust it according to reference of other climbers. This procedure has to precede the inclusion of each new route in the official climbing guides. Classification of climbing routes, or the scale of difficulty, is a measure system for comparison of climbers' performance. (Hejtmánek et al., 1996). An important standard for assessing performance is the style of ascent. Abbreviation OS (on sight) means climbing the route at the first attempt. Climber has no information about the route in advance; he or she has to climb at the first attempt as a leader and without falling or hanging in the rope. OS is the most appreciated style of ascent with rope (Procházka, 1990; Vomáčko \& Boštíková, 2003).

This paper is focused on the acceptable level of risk-taking at traditional rock climbing. Performance of climbers on sport climbing routes and their performance on traditional routes is compared. The aim of the 
research is to determine the level of risk-taking in traditional climbing on sandstone. The author focused on how the higher level of risk affects climber's performance and what reserve a climber needs to be able to cope with the higher risk and reduce it. It was assumed in the hypothesis that: The higher level of risk taking in traditional sandstone climbing decreases individual performance of climbers.

\section{MATERIAL AND METHODS}

\section{Participants}

Sample comprises the climbers engaged both in sport climbing and traditional sandstone climbing in traditional locations in Bohemia and Saxony.

Intentional selection criteria: Performance both on sport routes and traditional sandstone routes of at least the third degree of difficulty by OS style (on sight). The ratio of the frequency of sports climbing and climbing on the traditional sandstone routes was not regarded as significant.

304 active Czech rock climbers fulfilled the criteria. 258 were men (84,9\%) and 46 women (15,1\%).

\section{Performance Value}

In order to compare the performance of climbers, a unified scale for sport routes and traditional sandstone routes was designed, based on analyses and comparison of different classification scales available in the existing literature. The UIAA scale was set as a base for conversion and further comparison. The level of an intermediate of 0.5 was added. This level corresponds to the auxiliary values of "+" and "-". For example, degrees VI+ and VII- have their numeric value of 6.5. French and Saxon grading system was transferred to the UIAA scale according to the comparative tables (e.g., Dieška, 1989; Glowacz \& Pohl, 1999; Hatting, 1999; Heinicke, 2001; Vomáčko \& Boštíková, 2003). All the collected data were converted to the numeric values that fit statistical processing as a basic measured value - Performance Value. The UIAA scale contents figures and signs of "+", which means harder, and "-", which means easier, with reference to the preceding figure. The French scale contents figures and letters a, b, c, combined even with the sign of " + ". Saxon scale uses the Roman figures and letters from the level VII higher. All rating scales are ordinal; there is not the same distance between the consecutive levels. Conversion tables for comparing classification scales sometimes slightly vary in different sources. In this research study the "Performance Value" was designed as the basic unit and it enables conversion of different systems of climbing classification into a unified numerical scale. This numerical scale should eliminate the above-mentioned differences concerning existing classification scales.

One of the criteria was the style of ascent - OS was required, because there the number of attempts does not differ since the climbers must be successful at their first attempt. It is the most appreciated style of ascent. The climbers whose performance was lower than the third degree of difficulty in either discipline, and which indicated a significant disparity between climbing on sports routes and on sandstone rocks, were selected. The requirement was to climb at least 3 routes of the given difficulty. Unique performances reached on extreme favourable conditions were excluded. It was presumed that if a climber's performance was equal at least three times, it can be considered stable.

Risk index

Risk index (RI) was defined as a difference between performance on sport routes (SC) (low risk) and traditional sandstone routes $(\mathrm{TC}) . \mathrm{SC}=$ low risk, $\mathrm{TC}=$ high risk.

$\mathrm{RI}=\mathrm{SC}-\mathrm{TC}$ 


\section{Data collection}

Controlled-structured interview and questionnaire were used to collect data. As a control technique questioning of $10 \%$ of respondents were interviewed. Having used the method of structured questionnaire we collected information from climbers who engage in both selected disciplines. The basic sample consists of climbers who concern with sport climbing and climbing on traditional sandstone rocks, the key criterion was that the participants should be concerned with both mentioned disciplines. The majority of data were collected by a personal interview and several respondents filled in the questionnaire available on the website of the Czech Mountaineering Association.

\section{Statistical analysis}

Data analysis was carried out using the STATISTICA 10 program. Quantitative descriptive statistics and correlations were calculated. Student's parametric t-test and Wilcoxon nonparametric test for dependent samples were used. The minimum level of statistical significance was set at the level of probability $\alpha 0.05$. To determine the relationship of 2 ordinal traits we chose ordinal Spearman coefficient.

\section{RESULTS}

The average individual performance of climbers on sport routes varies between 6th and 7th degree of difficulty (Performance Value). The average individual performance of climbers on traditional sandstone routes ranges between 5th and 6th degree of difficulty (Performance Value) in majority of cases. An extreme shift to higher levels of performance in sport routes is noticeable. This shift corresponds to almost one full degree (0.94). The average of the individual performance on sport routes is 6.72 . It corresponds to $6+, 7-$ of the UIAA scale or $6 a, 6 a+$ of the French scale. The average of the individual performance on sandstone rocks is 5.78. It corresponds to the degree VII of the Saxon scale.

Table 1. Descriptive statistic - Performance Value

\begin{tabular}{|l|c|c|c|c|}
\hline \multicolumn{5}{|c|}{ Descriptive statistic - Performance value } \\
\hline & Average & Median & Modus & $\begin{array}{c}\text { Modus } \\
\text { frequency }\end{array}$ \\
\hline Performance value - sport routes & 6,72 & 6,5 & 6,5 & 66 \\
\hline Performance value - traditional routes & 5,77 & 5,5 & 6,5 & 56 \\
\hline
\end{tabular}




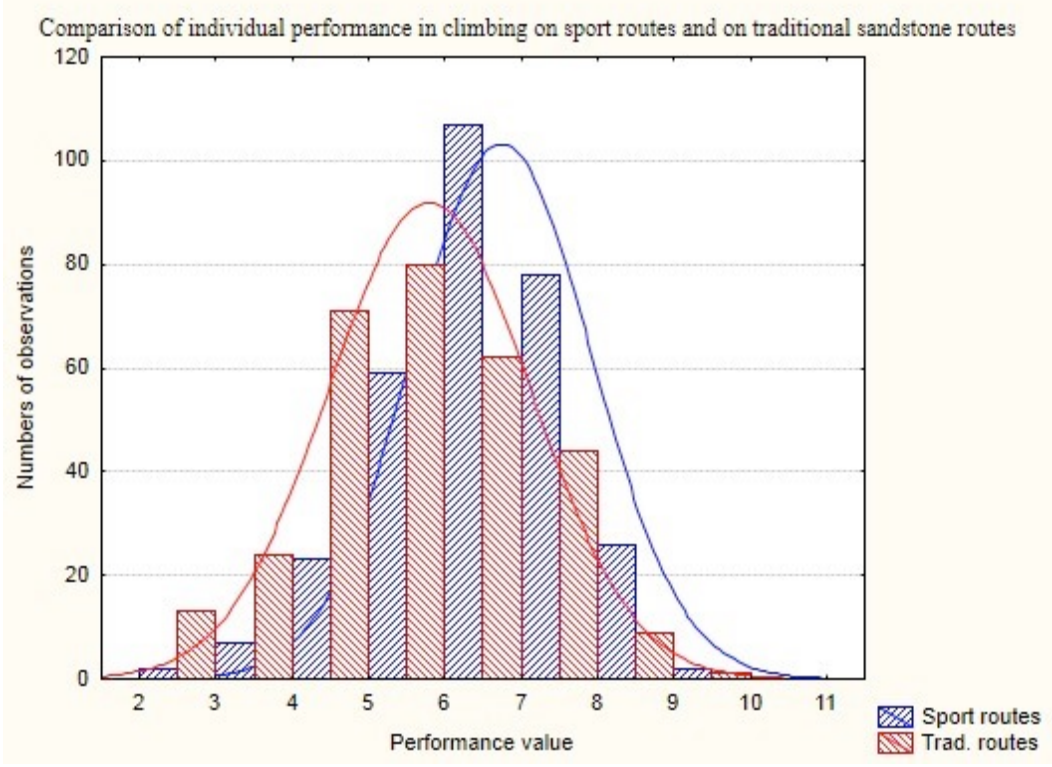

Figure 1. Comparison of individual performance in climbing on sport routes and on traditional routes

Average values of the individual performance of climbers are 6.5 for sport routes and 5.5 for traditional sandstone rocks. Student's parametric t-test and Wilcoxon nonparametric test for dependent samples showed a significant difference between the extreme individual performance on sport routes and sandstone rocks $(\alpha 0.05)$.

253 climbers (83\%) reported higher individual performance on sports routes, 16 climbers (5.3\%) reported higher individual performance on traditional sandstone rocks and $35(11.5 \%)$ climbers had a same performance in both disciplines. Correlation coefficient of extreme individual performance in sport climbing and traditional sandstone rock climbing has the value of 0.81 .

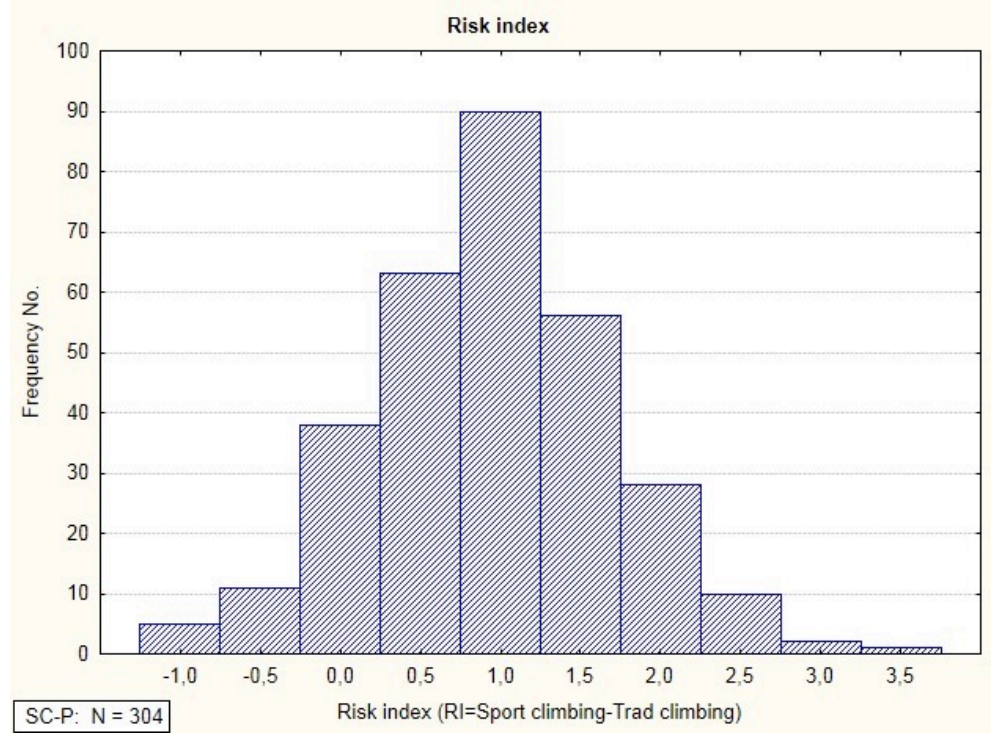

Figure 2. Risk index 
Risk Index (the average difference in climbing performance in the selected disciplines) is 0.94 , which is significant.

\section{DISCUSSION}

The research showed a lower level of the maximum performance of climbers on traditional sandstone routes compared to sport routes. Assumption that most climbers are more limited by fear when climbing on the traditional sandstone rocks, as a consequence of level of risk was confirmed. The results are in accord with psychologists. A higher level of risk decrease individual performance (Mikšík, 1969; Machač \& Machačová, 1988; Hošek, 1984). On the other hand, different people can react to psychological stress differently. Some authors describe that individuals can reach their maximum performance when stressed with fear (Hošek, 1994).

Each climber has different level of acceptable risk-taking in rock climbing but lower performance on less protected traditional routes is significant.

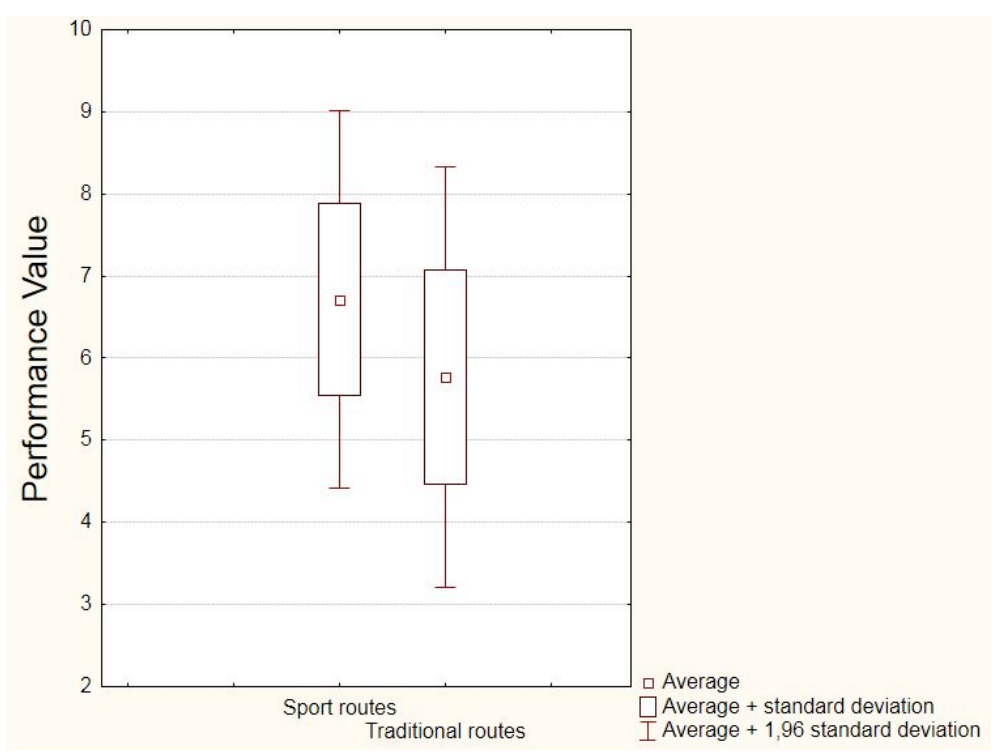

Figure 3. Sport climbing and traditional climbing Performance Value

\section{CONCLUSION}

The research focused on the difference in performance of climbers on sport routes and traditional sandstone routes.

Hypothesis, assuming that the higher level of risk taking in traditional sandstone climbing decreases individual performance of climbers, was verified. Climbers usually reach lower performance according to classification scale when climbing on traditional routes with a higher level of risk. The individual performance of climbers is in accordance with the scale of difficulty lower on traditional sandstone (high risk) routes than individual performance on sport (low risk) routes.

The results of the research proved a significant difference of climbers' performance in dependence on rate of risk. 


\section{REFERENCES}

1. Brody, E.B., Hatfield, B.D. \& Spalding, T.W. (1988). Generalization of self-efficacy to a continuum of stressors upon mastery of a high-risk sport skill. Journal of Sport and Exercise Psychology, 10(1), pp.32-44.

2. Český Horolezecký Svaz. (2013). Pravidla sportovniho lezení na pískovcových skalách v Čechách. Retrived from http://www.horosvaz.cz/res/data/058/010523

3. Dieška, I. (1989). Horolezectvi: Ecyklopédia. Bratislava: Šport.

4. Dieška, I. \& Širl, V. (1989). Horolezectví zblízka. Praha: Olympia.

5. Ewert, A.W. (1994). Playing the edge: Motivation and risk taking in a high-altitude wilderness like environment. Environment and Behavior, 26(1), pp.3-24.

6. Glowacz, S. \& Pohl, W. (1999). Volné lezení, České Budějovice: Kopp.

7. Hatting, G. (1990). Horolezectví. Praha: Svojtka \& Co.

8. Heinicke, D. (2001). Kletterführer Sächsische Schweiz: Band Gebiet der Steine, Dresden: Berg- \& NaturVerlag Peter Rölke.

9. Hejtmánek, P., Homolka, M. \& Sochor, J. (1996). Hruboskalsko: Skalák, I. dill, Dračí skály, Zámecká rokle, Jablonec nad Nisou: Hejtmánek.

10. Hošek, V. (1984). Vliv strachu na sportovní činnost. In: Vaněk, M aj. Psychologie sportu. Brno: SPN.

11. Hošek, V. (1994). Psychologie odolnosti. Praha: Karolinum.

12. Jones, G., Asghar, A. \& Llewellyn, D.J. (2008). The epidemiology of rock climbing injuries. $\mathrm{Br} J$ Sports Med, 42(9), pp.773-8.

13. Llewellyn, D.J. \& Sanchez, X. (2008). Individual differences and risk taking in rock climbing. Psychology of Sport and Exercise, 9, pp.413-426.

14. Llewellyn, D.J., Sanchez, X., Asghar, A. \& Jones, G. (2008). Self-efficacy, risk taking and performance in rock climbing. Personality and Individual Differences, 45, pp.75-81.

15. Machač, M. \& Machačová, H. (1998). Vliv strachu a úzkosti na regulaci činnosti. In: Machač, M., Machačová, H., Hoskovec, J. Emoce a výkonnost. Praha: SPN.

16. Mikšík, O. (1969). Člověk a svízelné situace. Praha: Naše vojsko.

17. Neuman, J. (1999). Překážkové dráhy, lezecké stěny a výchova prožitkem, Praha: Portál.

18. Neuman, J. et al. (2000). Turistika a sporty v prírodě, Praha: Portál.

19. Pain, M.T. \& Pain, M.A. (2005). Risk taking in sport. Lancet, 366(Suppl.1), pp.S33-S34.

20. Procházka, V. 1(990). Horolezectví, Praha: Olympia.

21. Robinson, D.W. (1985). Stress seeking: Selected behavioral characteristics of elite rock climbers. Journal of Sport Psychology, 7, pp.400-404.

22. Slanger, E. \& Rudestam, K.E. (1997). Motivation and disinhibition in high risk sports: Sensation seeking and self-efficacy. Journal of Research in Personality, 31(3), pp.355-374.

23. Turner, C., McClure, R. \& Pirozzo, S. (2004). Injury and risk-taking behavior - A systematic review. Accident Analysis and Prevention, 36(1), pp.93-101.

24. Vomáčko, S. \& Boštíková, S. (2003). Lezení na umělých stěnách: bouldering a obtižnost, bezpečné lezení, trénink, jak s dětmi, Praha: Grada.

25. Wright, D.M., Royle, T.J. \& Marshall, T. (2001). Indoor rock climbing: Who gets injured? British Journal of Sports Medicine, 35(3), pp.181-185.

26. Zuckerman, M. (1994). Behavioral expressions and biosocial bases of sensation seeking. Cambridge: Cambridge University Press. 